\title{
Friction Crush Welding of Similar Metals: An Overview
}

\author{
Prem Singh $^{1}$, Dharmpal Deepak ${ }^{2}$ and Gurinder Singh Brar ${ }^{3}$ \\ ${ }^{1}$ Department of Mechanical Engineering, Guru Nanak Dev Engineering College, Ludhiana, Punjab, India \\ ${ }^{2}$ Mechanical Engineering Department, Punjabi University, Patiala., Punjab, India \\ ${ }^{3}$ Department of Mechanical Engineering, National Institute of Technology, Srinagar (Garhwal) Uttarakhand, India \\ E-mail: er.premsingh@gmail.com
}

\begin{abstract}
Friction Crush Welding (FCW) is a newly developed technique which can be used for welding of similar materials with or without filler metal. In this process, welding between two work pieces occurs due to relative motion between work pieces and rotating cylindrical tool, which causes crushing of material to produce weld. Similar weld which include welds of aluminium, steel and copper and their alloy have been successfully produced by few researchers. This review covers the work conducted in the field of FCW and throws light on the future use of FCW for welding similar and dissimilar materials.
\end{abstract}

Keywords: Friction Crush welding, Aluminum, Steel, Microstructure, Scanning Electron Microscope.

\section{INTRODUCTION}

Friction Crush Welding (FCW) is a newly developed technique by Besler et al. (2016) using crushing of metal and was initially applied to weld simlilarsheet metals of aluminium, steel and copper without filler material. In this process, welding between two work pieces occurs due to relative motion between work pieces and rotating cylindrical tool having specific profile shape as shown in Fig. 1.

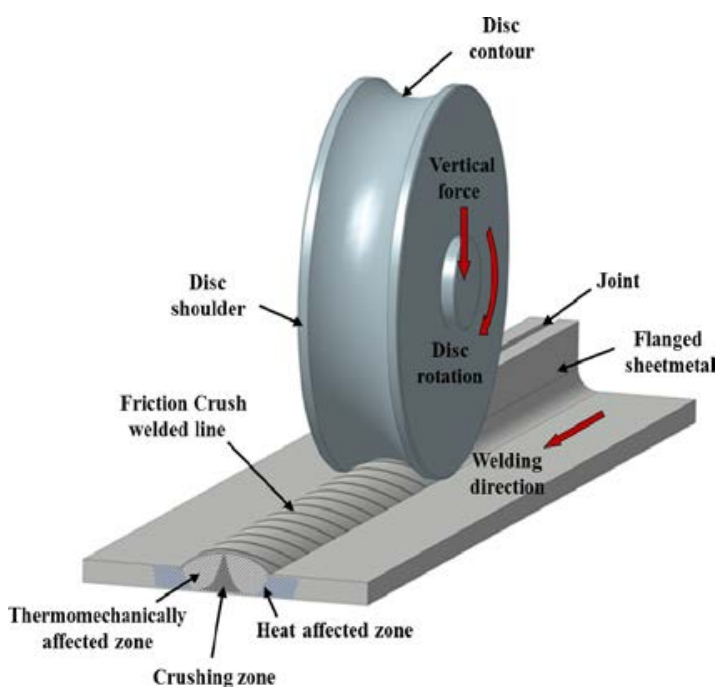

Fig. 1 Schematic illustration of FCW $[1,2,3,4]$

The workpieces having flanges on it are positioned adjacent to each other with a gap. The relative motion between tool and workpieces causes crushing of material and crushed material is filled into the gap between the two workpieces through the tool and produces weld.

FCW joints commonly consists of different microstructural zones as shown in Fig. 2. Which consists of unaffected material or original material, the heat affected zone (HAZ), thermo-mechanically affected zone (TMAZ) and crushing zone (CZ).

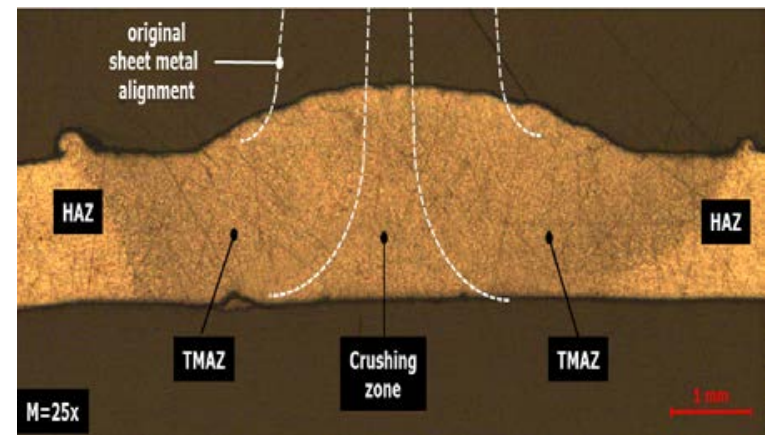

Fig. 2 Illustration of different microstructural regions in the transverse cross section of a FCW material (Steel) [2]

Prior to the development of FCW, conventional fusion welding processes along with friction stir welding (FSW) processes were used to join similar and dissimilar materials. Reviews have been conducted on various aspects of FSW by different researchers. This paper presents a review of published literature in FCW of similar materials. The review was conducted by focusing on FCW between similar material of aluminum, steel and copper.

\section{FRICTION CRUSH WELDING MECHANISM}

Friction crush welding mainly depends upon a) frictional heat produce due to relative motion

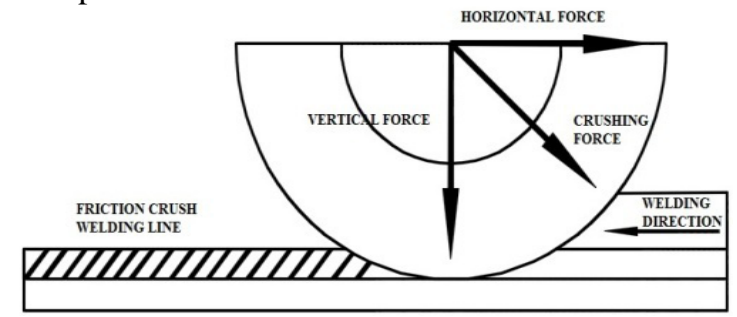

Fig. 3: Mechanism of friction crush welding [1,2]

between the work piece and the tool and b) crushing forces were developed by tool movement due to variation in 
welding speed and rotation of tool. The flanges of work pieces are crushed and filled into the gap between to plates to produce weld joint.Tool rotation and movement between tool and work piece cause development of tree types of forces in tool namely i) Horizontal force $\left(\mathrm{F}_{\mathrm{h}}\right)$, which acts in opposite to the welding direction, ii) Crushing force $\left(\mathrm{F}_{\mathrm{c}}\right)$, which crush the material and iii) Vertical downward force $\left(F_{v}\right)$, which held to fill the crushed material into gap between the two plates to produce weld.

\section{TOOL GEOMETRY AND JOINT DESIGN:}

Tool geometry and joint design plays an important an important role to produce good weld joint. Tool geometry or tool profile is described by various parameters like Outside dics diameter $(D)$, Disc width $\left(\mathrm{W}_{\mathrm{d}}\right)$, Profile or curvature of disc $\left(\mathrm{d}_{\mathrm{c}}\right)$, Groove width $\left(\mathrm{W}_{\mathrm{c}}\right)$ and disc shoulder $(\mathrm{S})$.
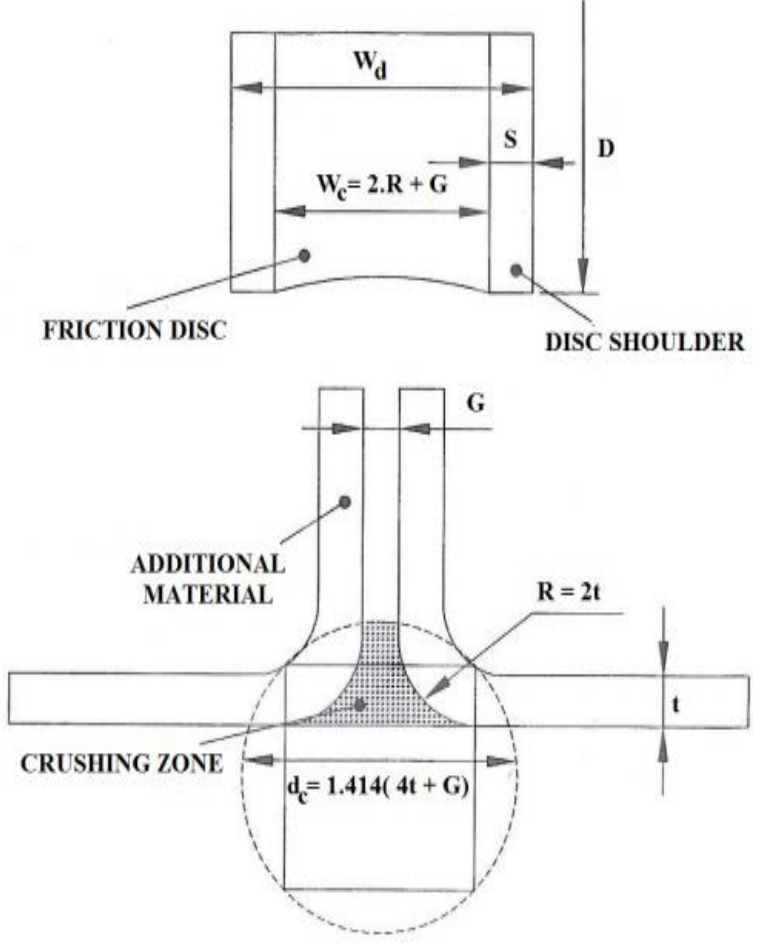

Fig. 4 Tool geometry and joint design $[1,3,4]$

With the help of tool geometry (Fig. 4), the curvature of disc $\left(\mathrm{d}_{\mathrm{c}}\right)$ is given as,

$d_{c}=1.414 \times(4 t+\mathrm{G})$

where, $\quad t=$ thickness of plates

$\mathrm{G}$ = gap between to plates

$\mathrm{R}=$ Outer radius of work piece when flanged $=2 \mathrm{t}$

Joint design plays an important role in FCW because additional material required to fill the gap between the two plates to be welded will be provided from the calculated height of flanges of plates. The height of flanges can be calculated by equating the volume of material required in crushing zone to produce weld from volume of material from flanges of plates.

Let $F=$ Length of flange

$A=$ Excess length of flange

$\mathrm{V}_{1}=$ Volume of gap between to plates
$\mathrm{V}_{2}=$ Volume of material under the curvature of bend plates

$\mathrm{V}_{3}=$ Volume of additional material required

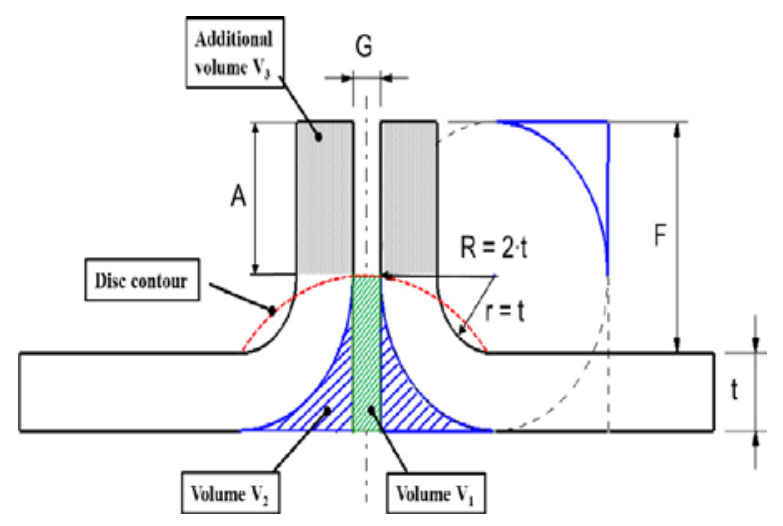

Fig. 5 Additional material volume [1,3]

As the volume of additional material required in crushing zone is to be supplied from volume of extra flange length, so

From Fig. 5,

$$
\mathrm{V}_{3}=\mathrm{V}_{1}+\mathrm{V}_{2}
$$

$$
\begin{aligned}
V_{1} & =2 t \times G \times L \\
V_{2} & =2\left(2 t \times 2 t \times L-1 / 4 \times \pi \times R^{2} \times L\right) \\
& =1 / 2 \times L\left[(4 t)^{2}-(2 t)^{2} \times \pi\right] \\
V_{3} & =A \times 2 t \times L
\end{aligned}
$$

Where, $\mathrm{L}=$ Length of weld

Using above relations, length of additional flange required to provide material in crushing zone can be described in terms of thickness of plate and gap between the plates as

$$
A=G+(4 t-\pi t)
$$

Total length of flange, $\mathrm{F}=\mathrm{A}+\mathrm{t}$

\section{RESEARCH ON FSW OUTSIDE INDIA}

Besler et al. [2,3] successfully demonstrated the butt joining of similar materials like Aluminium, steel and cooper by FCWwith and without additional material.Quality of weld was measured in terms of bond strength and microstructural analysis as per DIN EN ISO 4136 and EN ISO 17639 European standards respectively.

\section{A. Bond Strength}

Welding joints ofAluminium (EN AW5754 H22), steel (DC01) and cooper (DHP) were prepared with FCW at different welding speed $(\mathrm{mm} / \mathrm{min})$ and result of weld bond strength were compared with respective bond strength of base material.

Table I shows the tensile/bond strength of aluminium material joint at different welding speed with and without filler material, maximum bond strength with and without filler material observed was $190 \mathrm{~N} / \mathrm{mm}^{2}$ and $220 \mathrm{~N} / \mathrm{mm}^{2}$ at weld speed of 1000-1500 rpm/min and $500 \mathrm{rpm} / \mathrm{min}$ respectively. Aluminium weld shows maximum bond efficiency of $78 \%$ and $90 \%$ with and without filler material. 
With varying welding speed from $500 \mathrm{rpm} / \mathrm{min}$ to 3000 $\mathrm{rpm} / \mathrm{min}$, range of bond strength changes from $70-220$ $\mathrm{N} / \mathrm{mm}^{2}$ to $135-190 \mathrm{~N} / \mathrm{mm}^{2}$.

TABLE I TENSILE/BOND STRENGTH OF ALUMINIUM MATERIAL JOINT AT DIFFERENT WELDING SPEED WITH AND WITHOUT FILLER MATERIAL (ALUMINIUM PARENT BOND STRENGTH $=245 \mathrm{~N} / \mathrm{MM}^{2}$ )

\begin{tabular}{|c|c|c|}
\hline \multirow{2}{*}{$\begin{array}{c}\text { Welding } \\
\text { speed } \\
(\mathbf{m m} / \mathbf{m i n})\end{array}$} & \multicolumn{2}{|c|}{ Tensile/bond strength $\mathbf{( N / \mathbf { m m } ^ { \mathbf { 2 } } )}$} \\
\cline { 2 - 3 } & $\begin{array}{c}\text { With filler } \\
\text { material }\end{array}$ & $\begin{array}{c}\text { Without filler } \\
\text { material }\end{array}$ \\
\hline 500 & 180 & 220 \\
\hline 1000 & 190 & 172 \\
\hline 1500 & 190 & 150 \\
\hline 2000 & 160 & 132 \\
\hline 3000 & 135 & 70 \\
\hline
\end{tabular}

Table II shows the tensile/bond strength of steel material joint at different welding speed with and without filler material, maximum bond strength with and without filler material observed was $325 \mathrm{~N} / \mathrm{mm}^{2}$ and $305 \mathrm{~N} / \mathrm{mm}^{2}$ at weld speed of $2000 \mathrm{rpm} / \mathrm{min}$ and $1500-2000 \mathrm{rpm} / \mathrm{min}$ respectively. Steel weld shows maximum bond efficiency of $96 \%$ and $90 \%$ with and without filler material. Bond strength improves with filler material at respective weld speed.

TABLE II TENSILE/BOND STRENGTH OF STEEL MATERIAL JOINT AT DIFFERENT WELDING SPEED WITH AND WITHOUT FILLER MATERIAL (STEEL

\begin{tabular}{|c|c|c|}
\hline \multicolumn{3}{|c|}{ PARENT BOND STRENGTH $=338 \mathrm{~N} / \mathrm{MM}^{2}$ ) } \\
\hline \multirow{2}{*}{$\begin{array}{l}\text { Welding speed } \\
(\mathrm{mm} / \mathrm{min})\end{array}$} & \multicolumn{2}{|c|}{ Tensile/bond strength $\left(\mathrm{N} / \mathrm{mm}^{2}\right)$} \\
\hline & $\begin{array}{c}\text { With filler } \\
\text { material }\end{array}$ & $\begin{array}{c}\text { Without filler } \\
\text { material }\end{array}$ \\
\hline 1000 & 225 & 150 \\
\hline 1500 & 308 & 305 \\
\hline 2000 & 325 & 305 \\
\hline 2500 & 318 & 158 \\
\hline 3000 & 218 & -- \\
\hline 3500 & 192 & -- \\
\hline
\end{tabular}

TABLE III TENSILE/BOND STRENGTH OF COPPER MATERIAL JOINT AT DIFFERENT WELDING SPEED WITH AND WITHOUT FILLER MATERIAL $\left(\right.$ COPPER PARENT BOND STRENGTH $=264$ N/MM ${ }^{2}$ )

\begin{tabular}{|c|c|c|}
\hline \multirow{2}{*}{$\begin{array}{l}\text { Welding speed } \\
(\mathrm{mm} / \mathrm{min})\end{array}$} & \multicolumn{2}{|c|}{ Tensile/bond strength (N/mm²) } \\
\hline & $\begin{array}{c}\text { With filler } \\
\text { material }\end{array}$ & $\begin{array}{c}\begin{array}{c}\text { Without filler } \\
\text { material }\end{array} \\
\end{array}$ \\
\hline 1000 & -- & 82 \\
\hline 2000 & -- & 107 \\
\hline 3000 & 150 & 116 \\
\hline 4000 & 178 & 144 \\
\hline 5000 & 167 & 162 \\
\hline 6000 & 178 & 156 \\
\hline 7000 & 195 & -- \\
\hline 8000 & 164 & -- \\
\hline
\end{tabular}

Table III shows the tensile/bond strength of copper material joint at different welding speed with and without filler material, maximum bond strength with and without filler material observed was $195 \mathrm{~N} / \mathrm{mm}^{2}$ and $162 \mathrm{~N} / \mathrm{mm}^{2}$ at weld speed of $7000 \mathrm{rpm} / \mathrm{min}$ and $5000 \mathrm{rpm} / \mathrm{min}$ respectively. Copper weld shows maximum bond efficiency of $73 \%$ and $61 \%$ with and without filler material. Bond strength improves with filler material at respective weld speed.

\section{B.Macro-structural and Visual Inspections}

The geometry of the weld joint profile with its dimensions and surface characterization giving the average roughness value with and without filler material is given in table IV. The root sides of the three welded materials revealed a sound bond without any grooves or irregularities.

TABLE IV MACRO-STRUCTURAL ANALYSES OF WELD (LENGTH OF WELD = $15 \mathrm{MM}$, WIDTH OF WELD = 6MM)

\begin{tabular}{|c|c|c|}
\hline \multirow{2}{*}{ Materials } & \multicolumn{2}{|c|}{ Average Roughness (Ra) in $\mathbf{~ m}$} \\
\cline { 2 - 3 } & Without filler material & With filler material \\
\hline Aluminium & 6.64 & 6.44 \\
\hline Steel & 3.55 & 3.55 \\
\hline copper & 2.78 & 2.78 \\
\hline
\end{tabular}

Surfaces of weld prepared with and without filler material shows same quality as shown in table IV. Author reported minimal indications of material distortion after welding specially in case of weld produced with filer material.

\section{RESEARCH ON FSW IN INDIA}

Brar and Jamwal[3] prepared a weld joint of aluminium alloy (6061 T-6) with FSW at three tool rotating speed (220 rpm, $410 \mathrm{rpm}$ and $740 \mathrm{rpm}$ ) along with three different feed rate $(15 \mathrm{~mm} / \mathrm{min}, 30 \mathrm{~mm} / \mathrm{min}$ and $45 \mathrm{~mm} / \mathrm{min})$. The bond strength of the weld is measured by UTM machine. The result (Table 5) reveals that maximum bond strength was achieved with increase in rotational speed of tool as well as feed rate.

Brar et al.[4] optimized the process parameter of FSW of stainlesssteel (AISI 304) with the help of analysis software MINITAB 15 for design and analysis of experiments in order to perform Taguchi L9 orthogonal and ANOVA analysis. Result shows optimum welding conditions for AISI 304 stainless steel were $740 \mathrm{rpm}$ with feed rate 45 $\mathrm{mm} / \mathrm{min}$ for B profile rotating tool. The predicted and experimental bond strength at optimum weld conditions is $13.69 \mathrm{kN}$ and $10.03 \mathrm{kN}$ respectively with $4.84 \%$ error.

TABLE V VARIATIONBOND STRENGTH OF ALUMINIUM ALLOY (6061 T-6) WITH RESPECT TO TOOL ROTATIONAL SPEED CORRESPONDING TO FEED

\begin{tabular}{|c|c|c|}
\hline $\begin{array}{c}\text { Tool rotational speed } \\
\text { (rpm) }\end{array}$ & $\begin{array}{c}\text { Feed rate } \\
(\mathbf{m m} / \mathbf{m i n})\end{array}$ & $\begin{array}{c}\text { Bond strength } \\
(\mathbf{k N})\end{array}$ \\
\hline 220 & 15 & 5.1 \\
\hline 410 & 30 & 6.5 \\
\hline 740 & 45 & 7.4 \\
\hline
\end{tabular}




\section{CONCLUSIONS}

In conclusion, an overview of friction crush welding of similar materials focusing on aluminum, steel and copper and there alloys has been conducted along with fundamental of FCW mechanism, tool geometry and tool design. Furthermore most of the cited research studies are more focused on understanding the microstructure properties, bond strength of welds and evaluation of optimum welding parameters. A maximum bond strength of order of $96 \%$ with respect to their base metal shows on of the positive aspect of FCW as compare to other welding option available today.

\section{REFERENCES}

[1] F.ABesler, P.Schindele, R.J.Grant and M.J.R. Stegmuller, "Friction crush welding of aluminium, copper and steel sheet metals with flanged edges," Journal of Materials Processing Technology, Vol. 234, pp. 72-83, 2016.

[2] F. A.Besler, R.J.Grant, P.Schindele and M.J.R.Stegmuller, "Advanced Process Possibilities in Friction Crush Welding of Aluminum, Steel, and Copper by Using an Additional Wire”Metallurgical and Materials Transactions B, Vol. 48B, pp. 2930-2948, 2017.

[3] G.S.Brar and A.S. Jamwal, "Friction Crush Welding of Aluminium Alloy 6061 T-6,” International Journal of Advanced Multidisciplinary Research, Vol. 9, No. 2, pp. 101-104, 2017.

[4] G.S.Brar, M.Singh and A.S. Jamwal, "Process Parameter Optimization of Friction Crush Welding (FCW) of AISI 304 Stainless Steel,"Proceedings of the ASME 2017 International Mechanical Engineering Congress and Exposition (IMECE-2017) November 3-9, 2017, Tampa, Florida, USA, pp. 1-5, 2017. 